\title{
EVALUATION OF RHIZOBIA STRAINS UFLA 02100 AND CIAT 899 IN LINE LEP 0211 OF Phaseolus vulgaris L.
}

\author{
AVALIAÇÃO DAS ESTIRPES DE RIZÓBIO UFLA 02100 E CIAT 899 NA \\ LINHAGEM LEP 0211 DE Phaseolus vulgaris $L$.
}

\section{Cassiele Uliana FACCO ${ }^{1}$; Carlos Alberto de Bastos ANDRADE ${ }^{1}$; Guilherme Fernando CAPRISTO-SILVA ${ }^{2}$; Carlos Antonio da SILVA JUNIOR ${ }^{3}$; Ana Claudia Sossai SOUZA ${ }^{4}$}

1. Programa de Pós-graduação em Genética e Melhoramento de Plantas, Universidade Estadual de Maringá (PGM-UEM), Maringá PR, Brasil. cassieleuliana @ hotmail.com; 2. Programa de Pós-graduação em Agronomia, Universidade Estadual de Maringá (PGAUEM), Maringá - PR, Brasil, 3. Universidade do Estado de Mato Grosso (UNEMAT), Sinop - MT, Brasil; 4. Programa de Pósgraduação em Agronomia, Universidade Estadual de Maringá (PGA-UEM), Maringá - PR, Brasil.

\begin{abstract}
The growing quest for sustainability in agricultural production systems has been pushing researchers to develop new technologies under different soil and climatic conditions. Based on this, and knowing the socioeconomic importance of the bean, the use of biological nitrogen fixation (BNF) is explored. Thus, the quest for quantitative knowledge of BNF at the phenological stages in a new bean line using promising and commercial strains becomes necessary. The objective of this study was to evaluate the strains UFLA 02100 and CIAT 899 in the different phenological stages of the LEP 0211 common bean strain using the biological nitrogen fixation. The experiment was conducted in a greenhouse on the Maringá-PR campus of the State University of Maringá. The design was a randomized complete block design in a $6 \times 4$ factorial scheme with four replications. The factor A comprised six nitrogen sources: Control, strain UFLA 02 100, strain CIAT 899, Nitrogen $60 \mathrm{~kg} \mathrm{ha}^{-1}$, strain UFLA 02100 + Nitrogen $30 \mathrm{~kg} \mathrm{ha}^{-1}$, strain CIAT 899 + Nitrogen $30 \mathrm{~kg} \mathrm{ha}^{-1}$ and the B factor is the phenological stages V4, R5, R6 and R8. The analyzed variables were: dry mass of nodules (DMN, grams/plant), dry mass of shoot (DMS, grams/plant), nitrogen content in shoot (NCS, \%) and accumulation of nitrogen in shoot (ANS, grams/plant). For the statistical analysis of the data, the means test was used for the variables in the stages. The CIAT 899 strain statistically outperformed UFLA 02100 for most variables and it was found that nitrogen fertilization negatively affected nodulation.
\end{abstract}

KEYWORDS: Inoculation of seeds. Phenological stages. Biological fixation of nitrogen.

\section{INTRODUCTION}

The common bean (Phaseolus vulgaris L.) is one of the most important legumes in Brazil; together with rice, it encompasses not only economical but also social and cultural dimensions, since it is present at the table of most Brazilians regardless of their social class (VIEIRA et al., 2008).

Bean cultivation demands more nutrients, of which nitrogen is the most limiting because it is the most extracted and exported nutrient of the plants. Nitrogen comes from the soil, nitrogen fertilizers, and biological fixation of atmospheric N2 (BFA). In addition, there is a small contribution from $\mathrm{N} 2$ reaction, resulting in the formation of nitrate, which is added to the soil and represents roughly $4 \%$ of the positive nitrogen balance in the soil (HUNGRIA et al., 2001).

The BFA process involves the transformation of atmospheric $\mathrm{N} 2$ into ammonia (NH3) by specialized bacteria freely present in the environment, and is done solely or in association with plants (especially legumes), where the bacterium Rhizobium interacts with the host plant's root system via highly specialized structures called root nodes (CASSINI; FRANCO, 2008).

However, owing to the growing quest for sustainability in agricultural production systems, BFA has been an alternative source of input for the nitrogen fertilizer economy, in which these fertilizers can be supplemented (or even replaced) (BERGAMASCHI, 2006).

In view of the above, the objective of this work was to evaluate the biological nitrogen fixation capacity of the strains UFLA $02 \quad 100$ (Rhizobium etli) and CIAT 899 (Rhizobium tropici) in different phenological stages of the line LEP 02 11.

\section{MATERIAL AND METHODS}

The experiment was conducted in a greenhouse located in the campus of Maringá - PR, 
State University of Maringá (UEM), between August and November 2015 using the common bean line of the LEP 0211 black group.

The strains used were assigned by the Soil Microbiology Laboratory of the Department of Soil Science of the Federal University of Lavras UFLA/MG, grown in medium 79. The strain UFLA 02100 of Rhizobium etli was isolated in the state of Rondônia and showed with high efficiency in Leonard pots. This strain belongs to the collection of BFNN of the Laboratory of Soil Microbiology of UFLA/MG, efficient in establishing symbiosis with common bean and remains in the test phase. However, the CIAT 899 strain (SEMIA 4077) of Rhizobium tropici is authorized by the Ministry of Livestock and Supply (Ministério da Agricultura Pecuária e Abastecimento - MAPA) for the production of commercial bean inoculants (TOLEDO et al., 2009; BARBOSA; GONZAGA, 2012). In addition to the two strains, treatment without inoculation was used.

The soil used in the experiment was collected at the Experimental Farm of Iguatemi of the State University of Maringá (FEI/UEM), an area previously cultivated with grass and identified as eutroferric Red Nitosol according to Embrapa (2006), with the following characteristics of layer 0 - $0.20 \mathrm{~m}: \mathrm{pH}\left(\mathrm{H}_{2} \mathrm{O}\right)=6.0 ; \mathrm{Al}^{+3}\left(\mathrm{cmol}_{\mathrm{c}} \mathrm{dm}^{-3}\right)=0.0$; $\mathrm{Ca}+\mathrm{Mg}\left(\mathrm{cmol}_{\mathrm{c}} \mathrm{dm}^{-3}\right)=2.66 ; \mathrm{P}\left(\mathrm{mg} \mathrm{dm}^{-3}\right)=66.78$; $\mathrm{K}\left(\mathrm{cm}-1, \mathrm{dm}^{-3}\right)=0.23$; organic matter $\left(\mathrm{g} \mathrm{dm}^{-3}\right)=$ 12.26; $\mathrm{V}(\%)=47.59$; sum of bases $\left(\mathrm{cmol}_{\mathrm{c}} \mathrm{dm}^{-3}\right)=$ 2.89; CTC $\left(\mathrm{cm}^{-1}, \mathrm{dm}^{-3}\right)=6.07$. The experimental plots consisted of pots of plastic material with a total capacity of $0.005 \mathrm{~m}^{3}$, being allocated to benches in the greenhouse.

The soil used presented base saturation (V\%) of 47.59 and was corrected with dolomitic limestone in the dosage of $2,000 \mathrm{~kg} \mathrm{ha}^{-1}$ which was applied 60 days before sowing. The fertilization was carried out at the time of sowing, placing the fertilizer at $5 \mathrm{~cm}$ below and next to the seeds (COMISSÃO TÉCNICA SUL-BRASILEIRA DE FEIJÃO, 2012). Phosphate and potassium fertilization was the same for all plots and defined as a function of the soil analysis result, following the recommendations of Ribeiro et al. (1999).

We used $50 \mathrm{~kg}$ of $\mathrm{P}_{2} \mathrm{O}_{5}$ and $30 \mathrm{~h}^{-1} \mathrm{~kg} \mathrm{ha}^{-1}$ $\mathrm{K}_{2} \mathrm{O}$, having as source superphosphate and potassium chloride, both applied at sowing. Nitrogen fertilization, as part of the treatments, was $30 \mathrm{~kg} \mathrm{ha}^{-1}$ in combination with the strains, and $60 \mathrm{~kg}$ $\mathrm{ha}^{-1}$, being divided into $30 \mathrm{~kg} \mathrm{ha}^{-1}$ at the time of sowing and the other $30 \mathrm{~kg} \mathrm{ha}^{-1}$ in cover, when the plants were in the V3 phenological stage
(FERNÁNDEZ et al., 1986). The nitrogen source used was urea (45\% nitrogen).

Seed treatment was carried out 48 hours prior before to sowing with fungicide/insecticide at the dose of $200 \mathrm{~mL}$ of commercial product Standak ${ }^{\circledR}$ Top for $100 \mathrm{~kg}$ of seeds. After being treated, they were kept in the shade for later sowing. Five seeds per pot were used with subsequent thinning, with only two plants remaining.

The seeds were inoculated at the time of sowing with turfous inoculant in the dosage of $500 \mathrm{~g}$ to $50 \mathrm{~kg}$ of seeds, adding $5 \mathrm{~mL}$ of a $10 \%$ sugar solution in order to improve the adherence of the same to the seeds (PELEGRIM et al., 2009).

The experimental design was a randomized block design in a $6 \times 4$ factorial scheme with four replications. The factor A comprised the six sources of Nitrogen: Control (without strain and without nitrogen), strain UFLA 02 100, strain CIAT 899, Nitrogen $60 \mathrm{~kg} \mathrm{ha}^{-1}$, strain UFLA $02100+$ Nitrogen $30 \mathrm{~kg} \mathrm{ha}^{-1}$, strain CIAT 899 + Nitrogen $30 \mathrm{~kg} \mathrm{ha}^{-1}$. The B factor were four phenological stages of the crop: V4, R5, R6 and R8, corresponding to 35, 42, 55 and 67 days after sowing, respectively.

The variables evaluated were: dry mass of nodules (DMN, grams/plant); dry mass in shoot (DMS, grams/plant) nitrogen content in shoot (NCS, \%) and accumulation of nitrogen in shoot (ANS, grams/plant).

For DMN, the root systems were washed for the removal of excess soil, together with the aid of a sieve to prevent nodule losses. Afterwards, the nodules were detached from the root system and added to petri dishes and taken to drying in an air circulation oven at $60^{\circ} \mathrm{C}$ and after obtaining a constant mass, were weighed in a $0.001 \mathrm{~g}$ precision scale, and for each sample was determined their respective DMN.

For the evaluation of the DMS, the samples were conditioned in Kraft paper bags and placed for drying in forced circulation air oven at a temperature of $60 \pm 2{ }^{\circ} \mathrm{C}$. After reaching a constant mass, the samples were weighed in the same $0.001 \mathrm{~g}$ precision scale. Afterwards, the samples were submitted to the milling process in Willey mill with a $1.0 \mathrm{~mm}$ sieve, for further determination of the nitrogen content in shoot (NCS).

NCS was carried out at the Food and Animal Nutrition Laboratory of the Animal Science Department (LANA-UEM). It was obtained according to methodology proposed by Sarruge \& Haag (1979). The milling was done in a mill and the NCS was calculated by the semi-microkjedhal method (total nitrogen). The calculation of the accumulation of nitrogen in shoot (ANS) was done 
by multiplying the DMS with the NCS, and then divided by 100 and its result expressed in grams per plant.

The response variables collected in the experiment were first submitted to the test of homogeneity of the variances by means of the Levene Test and normality of the errors by the Shapiro-Wilk Test, at 5\% probability. For the variables where the assumptions were not met, the data transformation was performed. The fixed alpha $(\alpha)$ value was $5 \%$.

Once the basic assumptions of the analysis of variance were met, and in the cases of significant effect, the means were compared by the $\mathrm{t}$ test $(\mathrm{p}<0.05)$ in the variables DMN, DMS, NCS and ANS in nitrogen sources and phenological stages factors. Analysis of variance was performed using the SISVAR® statistical analysis software (FERREIRA, 2010).

\section{RESULTS AND DISCUSSION}

The analysis of variance of the data showed a significant effect for the $\mathrm{N}$ source factors, stages and the interaction of the $\mathrm{N} x$ stage sources for all variables, showing that there are differences between the factors in question (Table 1).

Table 1. Summary of analysis of variance of data on dry mass of nodules (DMN, grams/plant), shoot dry mass (DMS, grams/plant), nitrogen content in shoot (NCS, \%) and accumulation of nitrogen in shoot (ANS, grams/plant) in the line LEP 0211 (Maringá - PR, Brazil).

\begin{tabular}{llllll}
\hline Variation Factor & DF & \multicolumn{2}{l}{ Mean Squares } & & NCS \\
\hline & & $\mathrm{DMN}^{1}$ & $\mathrm{DMS}^{1}$ & $\mathrm{ANS}^{1}$ \\
\cline { 2 - 6 } Sources N & 5 & $0.0345^{*}$ & $0.9028^{*}$ & $0.3568^{*}$ & $0.0048^{*}$ \\
Stadiums & 3 & $0.0446^{*}$ & $1.8732^{*}$ & $2.1299^{*}$ & $0.0027^{*}$ \\
Sources of N x Stadiums & 15 & $0.0046^{*}$ & $0.0266^{*}$ & $0.0542^{*}$ & $0.0009^{*}$ \\
Blocks & 3 & 0.0020 & 0.0092 & 0.0379 & 0.0001 \\
Error & 69 & 0.0009 & 0.0030 & 0.0158 & 0.0001 \\
\hline Total & 95 & - & - & - & - \\
\hline Coefficient of Variation $(\%)$ & & 3.69 & 2.84 & 7.73 & 11.87 \\
\hline Overall mean & & 0.82 & 1.93 & 1.63 & 0.05 \\
\hline
\end{tabular}

* Significant $(\mathrm{p} \leq 0.05) ;{ }^{1}$ Averages transformed through the function $\sqrt{x+0.5}$. DF $=$ Degrees of Freedom.

The distribution of the $\mathrm{N}$ source factor at each stage was significant $(\mathrm{p} \leq 0.05)$ for all variables, showing that there is a different behavior in the stages in relation to the $\mathrm{N}$ sources used (Table 2).

Table 2. Summary of the analysis of variance with the unfolding of $\mathrm{N}$ sources at each stage for the response variables to dry mass of nodules (DMN, grams/plant), dry mass in shoot (DMS, grams/plant), nitrogen content in shoot (NCS, \%) and accumulation of nitrogen in shoot (ANS, grams/plant) in line LEP 0211 (Maringá - PR, Brazil).

\begin{tabular}{llllll}
\hline Variation Factor & DF & \multicolumn{2}{l}{ Mean Squares } & \\
\hline & & DMN & DMS & NCS & ANS \\
\cline { 3 - 6 } Sources of N / Stadium V4 & 5 & $0.0023^{*}$ & $0.1193^{*}$ & $0.3748^{*}$ & $0.0010^{*}$ \\
Sources of N / Stadium R5 & 5 & $0.0037^{*}$ & $0.2345^{*}$ & $0.0658^{*}$ & $0.0010^{*}$ \\
Sources of N / Stadium R6 & 5 & $0.0077^{*}$ & $0.1955^{*}$ & $0.0492^{*}$ & $0.0010^{*}$ \\
Sources of N / Stadium R8 & 5 & $0.0346^{*}$ & $0.4332^{*}$ & $0.0298^{\text {ns }}$ & $0.0019^{*}$ \\
Error & 69 & 0.0009 & 0.0030 & 0.0158 & 0.0001 \\
\hline
\end{tabular}

* Significant $(\mathrm{p} \leq 0.05) . \mathrm{DF}=$ Degrees of Freedom.

According to Table 3, it is observed for DMN that the UFLA 02100 strain had an advantage in the V4 stage, but in the R5 and R6 stages it did not differ significantly from the CIAT 899 strain. At the R8 stage, the CIAT 899 + nitrogen source $30 \mathrm{~kg}$ $\mathrm{ha}^{-1}$ was the one with the highest dry mass of nodules.

According to Moreira and Siqueira (2002), even in the mutual symbiosis an initial transient parasitic stage occurs, in which the bacterium is not yet fixing and transferring nitrogen to the legume but is receiving photosynthates of the plant. In this case, it is shown that UFLA 02100 occurred a rapid infection and nodulation of the strain in the root, but still with low efficiency in the conversion of atmospheric $\mathrm{N}_{2}$ to the plant, reflecting in smaller values for the other variables in the V4 stage (Table $3)$. 
Valadão et al. (2009), working with the CIAT 899 strain in common bean, observed a significant difference in relation to treatment without inoculation. Reck (2014), evaluated four inoculants, among them the inoculant UFLA 02 100, which also verified significant differences among inoculants on DMN.

However, Fonseca et al. (2013) using the strain CIAT 899 and UFLA 04173 did not observe significant differences $(p>0.05)$ for the $D M N$ variable. According Ferreira et al. (2009), evaluating different inoculants, including CIAT 899 and UFLA 02100 strains, in addition to treatment without inoculation, did not find significant effects $(\mathrm{p}>0.05)$ for this variable.

The plants that were not inoculated with strains (control) and those that received nitrogen fertilization of $60 \mathrm{~kg} \mathrm{ha}^{-1}$, presented a similar behavior during the cycle and were the ones that presented smaller DMN in all the stages for the two strains studied (Table 3). These results corroborate those found by Valadão et al. (2009), who observed that nitrogen fertilization negatively affected nodulation thus reducing DMN.

For DMS, $60 \mathrm{~kg} \mathrm{ha}^{-1}$ showed better results in the first three stages observed (V4, R5 and R6), but the CIAT 899 strain added $30 \mathrm{~N} \mathrm{~kg} \mathrm{ha}^{-1}$ stage R8 that presented a higher DMS. The uninoculated control and the strain UFLA 02100 were the ones that presented lower DMS for this strain (Table 3). Brito et al. (2011), also verified that the nitrogen doses influenced the dry matter production of the shoot, because the application of nitrogen fertilization resulted in higher plants and with dry mass higher than the mass found in the absence of mineral $\mathrm{N}$. These results show that the use of nitrogen in the soil is easily absorbed by the root system of the common bean, optimizing its growth and dry matter accumulation (VALADÃO et al., 2009).

The supply of $\mathrm{N}$ in suitable amounts by the BNF can increase crop productivity at a low cost since the presence of a high $\mathrm{N}$ content in the leaves provides an increase in plant growth and yield. It is known that more than $50 \%$ of the $\mathrm{N}$ content in the leaf is the soluble protein ribulose-1.5-bisphosphate carboxylase/oxigenase (Rubisco), an enzyme responsible for the fixation of $\mathrm{CO}_{2}$ and synthesis of carbohydrates, which in turn allows accumulation of dry matter (LONG et al., 2006).

For NCS, nitrogen $60 \mathrm{~kg} \mathrm{ha}^{-1}$ was the source of $\mathrm{N}$ which maintained the best results for the NCS variable at all stages. All $\mathrm{N}$ sources were higher than control, and this in turn obtained the lowest NCS values at all stages (Table 3).

According Reck (2014), working with three common bean cultivars observed that the $\mathrm{N}$ content in shoot was higher with the use of nitrogen fertilization, both without inoculation, and with the inoculants with the strains UFLA 04 195, CIAT 899, UFLA 02127 and UFLA 02100.

In relation to the inoculants, Araújo et al. (2007) obtained a significant increase in the percentage of nitrogen in the leaves, when the bean seeds were inoculated with the CIAT 899 strain, in relation to the control.

For ANS, nitrogen fertilization $60 \mathrm{~kg} \mathrm{ha}^{-1}$ showed the best results in all observed stages (V4, R5, R6 and R8). However, in the R5 and R8 stages, the $\mathrm{N}$ source, $60 \mathrm{~kg} \mathrm{ha}^{-1}$ nitrogen, did not differ significantly from CIAT 899 strain with and without addition of $30 \mathrm{~kg} \mathrm{ha}^{-1}$ of $\mathrm{N}$. The control and the inoculant with strain UFLA 02100 were those that presented lower ANS for this line (Table 3). In general, there was a progressive increase in ANS with the development of the culture for all $\mathrm{N}$ sources.

Reck (2014), observed that the application of mineral nitrogen provided an increase in the accumulation of nitrogen in shoot in the three cultivars evaluated in their respective epochs, being the treatments with higher ANS the ones that also presented higher DMS. According to Figueiredo (2012), the accumulation of nutrients by plants, including $\mathrm{N}$, is proportional to accumulated dry matter. This fact can also be observed in the present work, where the sources with greater nitrogen accumulation in shoot were also those that obtained the greater dry mass in shoot.

The amount of nitrogen absorbed varies during the development cycle of the plant depending on the amount of roots and the rate of absorption per unit weight of root. Normally, this amount increases during the period of vegetative growth, reaches the maximum during the reproductive stages and falls during the grain filling stage (CREGAN; BERKUM, 1984). This fluctuation during the ontogeny of the plant is partly explained by the availability of nitrogen in the soil, but factors intrinsic to the plant have a relevant role in this process, such as the mechanisms of the amino acid cycle between stem and root and the supply from carbohydrates to roots (BREDEMEIER; MUNDSTOCK, 2000). 
Table 3. Mean values of dry mass of nodules (DMN, grams/plant), dry mass in shoot (DMS, grams/plant), nitrogen content in shoot (NCS, \%) and accumulation nitrogen in shoot ANS, grams/plant) as a function of interaction sources of N x stages in line LEP 0211 (Maringá - PR, Brazil).

\begin{tabular}{|c|c|c|c|c|}
\hline Sources N & DMN & DMS & NCS & ANS \\
\hline & V4 Stage & & & \\
\hline Control & $0.0696 \mathrm{~b}$ & $1.3076 \mathrm{~d}$ & $1.5625 \mathrm{c}$ & $0.0204 \mathrm{~d}$ \\
\hline UFLA 02100 & $0.1582 \mathrm{a}$ & $1.7335 \mathrm{c}$ & $1.9709 \mathrm{~b}$ & $0.0342 \mathrm{c}$ \\
\hline CIAT 899 & $0.1288 \mathrm{ab}$ & $2.1435 \mathrm{~b}$ & $2.3349 \mathrm{a}$ & $0.0500 \mathrm{~b}$ \\
\hline Nitrogen 60 & $0.0652 \mathrm{~b}$ & $2.6855 \mathrm{a}$ & $2.4306 \mathrm{a}$ & $0.0654 \mathrm{a}$ \\
\hline UFLA $02100+\mathrm{N} 30$ & $0.1399 \mathrm{a}$ & $2.4606 \mathrm{a}$ & $2.0374 \mathrm{~b}$ & $0.0500 \mathrm{~b}$ \\
\hline \multirow[t]{2}{*}{ CIAT $899+\mathrm{N} 30$} & $0.1157 \mathrm{ab}$ & $2.5986 \mathrm{a}$ & $2.0641 \mathrm{~b}$ & $0.0536 \mathrm{~b}$ \\
\hline & & R5 Stage & & \\
\hline Control & $0.0719 \mathrm{c}$ & $1.5098 \mathrm{~d}$ & $1.3729 \mathrm{~b}$ & $0.0207 \mathrm{~d}$ \\
\hline UFLA 02100 & $0.1751 \mathrm{a}$ & $2.4147 \mathrm{c}$ & $1.4663 \mathrm{~b}$ & $0.0354 \mathrm{c}$ \\
\hline CIAT 899 & $0.1824 \mathrm{a}$ & $3.5204 \mathrm{a}$ & $1.6702 \mathrm{a}$ & $0.0592 \mathrm{a}$ \\
\hline Nitrogen 60 & $0.0770 \mathrm{bc}$ & $3.5938 \mathrm{a}$ & $1.6847 \mathrm{a}$ & $0.0606 \mathrm{a}$ \\
\hline UFLA $02100+\mathrm{N} 30$ & $0.1437 \mathrm{ab}$ & $3.0432 \mathrm{~b}$ & $1.5131 \mathrm{ab}$ & $0.0460 \mathrm{~b}$ \\
\hline \multirow[t]{2}{*}{ CIAT $899+\mathrm{N} 30$} & $0.1622 \mathrm{a}$ & $3.6010 \mathrm{a}$ & $1.6529 \mathrm{a}$ & $0.0593 \mathrm{a}$ \\
\hline & & R6 Stage & & \\
\hline Control & $0.0729 \mathrm{~b}$ & $2.1467 \mathrm{e}$ & $1.3189 \mathrm{c}$ & $0.0286 \mathrm{e}$ \\
\hline UFLA 02100 & $0.2395 \mathrm{a}$ & $2.8409 \mathrm{~d}$ & $1.4363 \mathrm{bc}$ & $0.0408 \mathrm{~d}$ \\
\hline CIAT 899 & $0.1905 \mathrm{a}$ & $3.8608 \mathrm{~b}$ & $1.5360 \mathrm{ab}$ & $0.0595 \mathrm{~b}$ \\
\hline Nitrogen 60 & $0.0820 \mathrm{~b}$ & $4.4547 \mathrm{a}$ & $1.6367 \mathrm{a}$ & $0.0730 \mathrm{a}$ \\
\hline UFLA $02100+\mathrm{N} 30$ & $0.1768 \mathrm{a}$ & $3.5294 \mathrm{c}$ & $1.4209 \mathrm{bc}$ & $0.0501 \mathrm{c}$ \\
\hline \multirow[t]{2}{*}{ CIAT $899+\mathrm{N} 30$} & $0.2252 \mathrm{a}$ & $4.0524 \mathrm{~b}$ & $1.5298 \mathrm{ab}$ & $0.0619 \mathrm{~b}$ \\
\hline & & R8 Stage & & \\
\hline Control & $0.0862 \mathrm{c}$ & $2.5267 \mathrm{e}$ & $1.2710 \mathrm{~b}$ & $0.0321 \mathrm{~d}$ \\
\hline UFLA 02100 & $0.3533 \mathrm{~b}$ & $3.8340 \mathrm{~d}$ & $1.3694 \mathrm{ab}$ & $0.0526 \mathrm{c}$ \\
\hline CIAT 899 & $0.3186 \mathrm{~b}$ & $5.7847 \mathrm{~b}$ & $1.4364 \mathrm{ab}$ & $0.0830 \mathrm{a}$ \\
\hline Nitrogen 60 & $0.0823 \mathrm{c}$ & $5.7249 \mathrm{~b}$ & $1.4695 \mathrm{a}$ & $0.0842 \mathrm{a}$ \\
\hline UFLA $02100+\mathrm{N} 30$ & $0.3869 \mathrm{ab}$ & $4.7696 \mathrm{c}$ & $1.5193 \mathrm{a}$ & $0.0729 \mathrm{~b}$ \\
\hline CIAT $899+N 30$ & $0.4690 \mathrm{a}$ & $6.3458 \mathrm{a}$ & $1.3994 \mathrm{ab}$ & $0.0887 \mathrm{a}$ \\
\hline
\end{tabular}

Means followed by the same letter, in the columns, for each stage, do not differ by the t test, at $5 \%$ probability.

In the analysis of the unfolding of the effect of the stages in each source of $\mathrm{N}$, it was observed that there was a significant difference $(\mathrm{p} \leq 0.05)$ (Table 4) between the factors for the variable dry mass nodule response (except for control and N60), mass dry matter of the shoot, content of nitrogen in the aerial part and accumulation of nitrogen in shoot.

Table 4. Summary of the analysis of variance with the unfolding of the effect of the stages in each $\mathrm{N}$ source for the variables dry mass of nodules (DMN, grams/plant), dry mass in shoot (DMS, grams/plant), nitrogen content in shoot (NCS, \%) and accumulation of nitrogen in shoot (ANS, grams/plant) in the line LEP 0211 (Maringá - PR, Brazil).

\begin{tabular}{|c|c|c|c|c|c|}
\hline \multirow[t]{2}{*}{ Variation Factor } & \multirow[t]{2}{*}{ DF } & \multicolumn{4}{|c|}{ Mean Squares } \\
\hline & & DMN & DMS & NCS & ANS \\
\hline Stadiums/Controls & 3 & $0.0001^{\mathrm{ns}}$ & $0.1343^{*}$ & $0.0652^{*}$ & $0.0001^{*}$ \\
\hline Stadiums/UFLA 02100 & 3 & $0.0103^{*}$ & $0.2400^{*}$ & $0.3056^{*}$ & $0.0002 *$ \\
\hline Stadiums/CIAT 899 & 3 & $0.0087^{*}$ & $0.5220^{*}$ & $0.6566^{*}$ & $0.0007 *$ \\
\hline Stadiums/N 60 & 3 & $0.0001^{\mathrm{ns}}$ & $0.3629 *$ & $0.7289^{*}$ & $0.0004 *$ \\
\hline Stadiums/UFLA 02 100+N30 & 3 & $0.0182 *$ & $0.2345^{*}$ & $0.3139 *$ & $0.0005^{*}$ \\
\hline Stadiums/CIAT 899+N30 & 3 & $0.0303^{*}$ & $0.5125^{*}$ & $0.3309^{*}$ & $0.0009 *$ \\
\hline Error & 69 & 0.0009 & 0.0030 & 0.0158 & 0.0004 \\
\hline
\end{tabular}

* significant $(\mathrm{p} \leq 0.05) .{ }^{\mathrm{ns}}$ non-significant $(\mathrm{p}>0.05) . \mathrm{DF}=$ Degrees of Freedom. 
Table 5 shows that for the DMN variable there was no significant increase in the dry mass of nodules at stages V4, R5, R6 and R8 for the control source and $\mathrm{N} 60 \mathrm{~kg} \mathrm{ha}^{-1}$. However, in those plants that were inoculated there was a significant increase in the dry mass of nodules during the development of the culture in the above-mentioned stages, being that in the R8 stage a larger DMN is observed for these sources of $\mathrm{N}$ studied in both lines.

For DMS (Table 5), it is clear that as the development of the plants occurs in the phenological stages V4, R5, R6 and R8, there is a significant increase in shoot dry mass in all observed $\mathrm{N}$ sources, thus having the R8 stage with the highest DMS.
For NCS (Table 5), it is generally observed that there was a progressive decrease in NCS during the development of the crop in all sources of $\mathrm{N}$. According to Imsande \& Schmidt (1998), from the stage of development of pods there is a decrease of the nitrogen concentration in the vegetative part of the plant, because this nutrient is carried to the strongest drain of the plant, that is, the grains and the pods.

As shown in Table 5, it is observed that as the plants develop in the phenological stages V4, R5, R6 and R8, there is a significant increase in the accumulation of nitrogen in shoot in all observed $\mathrm{N}$ sources, being in the stage R8 where it is observed greater ANS. This same behavior was observed for the variable DMS, as previously described.

Table 5. Mean values of dry mass of nodules (DMN, grams/plant), dry mass of shoot (DMS, grams/plant), nitrogen content in shoot (NCS, \%) and accumulation nitrogen in shoot (ANS, grams/plant) as a function of the interaction stages and sources of N in line LEP 0211 (Maringá - PR, Brazil).

\begin{tabular}{|c|c|c|c|c|}
\hline Stadiums & DMN & DMS & $\mathrm{NCS}$ & ANS \\
\hline & Control & & & \\
\hline V4 Stage & $0.0696 \mathrm{a}$ & $1.3076 \mathrm{c}$ & $1.5625 \mathrm{a}$ & $0.0204 \mathrm{~b}$ \\
\hline R5 Stage & $0.0719 \mathrm{a}$ & $1.5098 \mathrm{c}$ & $1.3729 \mathrm{~b}$ & $0.0207 \mathrm{~b}$ \\
\hline R6 Stage & $0.0729 \mathrm{a}$ & $2.1467 \mathrm{~b}$ & $1.3189 \mathrm{~b}$ & $0.0283 \mathrm{ab}$ \\
\hline R8 Stage & $0.0862 \mathrm{a}$ & $2.5267 \mathrm{a}$ & $1.2710 \mathrm{~b}$ & $0.0321 \mathrm{a}$ \\
\hline \multicolumn{5}{|c|}{ UFLA 02100} \\
\hline V4 Stage & $0.1582 \mathrm{c}$ & $1.7335 \mathrm{~d}$ & $1.9709 \mathrm{a}$ & $0.0342 \mathrm{~b}$ \\
\hline R5 Stage & $0.1751 \mathrm{bc}$ & $2.4147 \mathrm{c}$ & $1.4663 \mathrm{~b}$ & $0.0354 \mathrm{~b}$ \\
\hline R6 Stage & $0.2395 \mathrm{~b}$ & $2.8409 \mathrm{~b}$ & $1.4363 \mathrm{~b}$ & $0.0408 \mathrm{~b}$ \\
\hline R8 Stage & $0.3533 \mathrm{a}$ & $3.8340 \mathrm{a}$ & $1.3694 \mathrm{~b}$ & $0.0526 \mathrm{a}$ \\
\hline \multicolumn{5}{|c|}{ CIAT 899} \\
\hline V4 Stage & $0.1288 \mathrm{~b}$ & $2.1435 \mathrm{~d}$ & $2.3349 \mathrm{a}$ & $0.0500 \mathrm{c}$ \\
\hline R5 Stage & $0.1824 \mathrm{~b}$ & $3.5204 \mathrm{c}$ & $1.6702 \mathrm{~b}$ & $0.0592 \mathrm{~b}$ \\
\hline R6 Stage & $0.1905 \mathrm{~b}$ & $3.8608 \mathrm{~b}$ & $1.5360 \mathrm{bc}$ & $0.0595 \mathrm{~b}$ \\
\hline R8 Stage & $0.3186 \mathrm{a}$ & $5.7847 \mathrm{a}$ & $1.4364 \mathrm{c}$ & $0.0830 \mathrm{a}$ \\
\hline \multicolumn{5}{|c|}{ N60 } \\
\hline V4 Stage & $0.0652 \mathrm{a}$ & $2.6855 \mathrm{~d}$ & $2.4306 \mathrm{a}$ & $0.0654 \mathrm{bc}$ \\
\hline R5 Stage & $0.0770 \mathrm{a}$ & $3.5938 \mathrm{c}$ & $1.6847 \mathrm{~b}$ & $0.0606 \mathrm{c}$ \\
\hline R6 Stage & $0.0820 \mathrm{a}$ & $4.4547 \mathrm{~b}$ & $1.6367 \mathrm{bc}$ & $0.0730 \mathrm{~b}$ \\
\hline R8 Stage & $0.0823 \mathrm{a}$ & $5.7249 \mathrm{a}$ & $1.4695 \mathrm{c}$ & $0.0842 \mathrm{a}$ \\
\hline \multicolumn{5}{|c|}{ UFLA 02 100+N30 } \\
\hline V4 Stage & $0.1399 \mathrm{~b}$ & $2.4606 \mathrm{~d}$ & $2.0374 \mathrm{a}$ & $0.0500 \mathrm{~b}$ \\
\hline R5 Stage & $0.1437 \mathrm{~b}$ & $3.0432 \mathrm{c}$ & $1.5191 \mathrm{~b}$ & $0.0460 \mathrm{~b}$ \\
\hline R6 Stage & $0.1768 \mathrm{~b}$ & $3.5294 \mathrm{~b}$ & $1.5133 \mathrm{~b}$ & $0.0501 \mathrm{~b}$ \\
\hline R8 Stage & $0.3869 \mathrm{a}$ & $4.7696 \mathrm{a}$ & $1.4209 \mathrm{~b}$ & $0.0729 \mathrm{a}$ \\
\hline \multicolumn{5}{|c|}{ CIAT $899+\mathrm{N} 30$} \\
\hline V4 Stage & $0.1157 \mathrm{c}$ & $2.5986 \mathrm{~d}$ & $2.0641 \mathrm{a}$ & $0.0536 \mathrm{~b}$ \\
\hline R5 Stage & $0.1622 \mathrm{bc}$ & $3.6010 \mathrm{c}$ & $1.6529 \mathrm{~b}$ & $0.0593 \mathrm{~b}$ \\
\hline R6 Stage & $0.2252 \mathrm{~b}$ & $4.0524 \mathrm{~b}$ & $1.5298 \mathrm{bc}$ & $0.0619 \mathrm{~b}$ \\
\hline R8 Stage & $0.4690 \mathrm{a}$ & $6.3458 \mathrm{a}$ & $1.3994 \mathrm{c}$ & $0.0887 \mathrm{a}$ \\
\hline
\end{tabular}

Means followed by the same letter, in the columns, for each source of $\mathrm{N}$, do not differ from each other, by the t test, at 5\% probability. 


\section{CONCLUSIONS}

The CIAT 899 strain statistically outperformed the UFLA 02100 strain in the greenhouse conducted for most variables and nitrogen fertilization adversely affected nodulation;
In view of the above, it is perceived that more research is needed in this area demonstrating the possibility of the crop benefiting from BNF, following the good practices of seed inoculation.

RESUMO: A crescente busca pela sustentabilidade nos sistemas de produção agrícolas vem impulsionando os pesquisadores a desenvolverem novas tecnologias nas diferentes condições edafoclimáticas. Com base nisso, e sabendo da importância socioeconômica do feijoeiro, o uso da fixação biológica de nitrogênio (FBN) é explorada. Assim, a busca do conhecimento quantitativo da FBN nos estádios fenológicos em uma nova linhagem de feijão utilizando estirpes promissoras e comerciais se torna necessário. Desta maneira, o objetivo foi avaliar as estirpes UFLA 02100 e CIAT 899 nos diferentes estádios fenológicos da linhagem de feijão comum LEP 0211 mediante o uso da fixação biológica de nitrogênio. O experimento foi conduzido em casa de vegetação no campus de Maringá-PR da Universidade Estadual de Maringá. O delineamento foi o de blocos ao acaso (DBC) em esquema fatorial $6 \times 4$ com quatro repetições. $\mathrm{O}$ fator $\mathrm{A}$ compreendeu seis fontes de nitrogênio: Testemunha, estirpe UFLA 02 100, estirpe CIAT 899, Nitrogênio $60 \mathrm{~kg}$ ha ${ }^{-1}$, estirpe UFLA $02100+$ Nitrogênio $30 \mathrm{~kg} \mathrm{ha}^{-1}$, estirpe CIAT 899+Nitrogênio $30 \mathrm{~kg} \mathrm{ha}^{-1}$ e o fator B os estádios fenológicos V4, R5, R6 e R8. As variáveis analisadas foram: massa seca de nódulos (MSN, gramas/planta), massa seca da parte aérea (MSPA, gramas/planta), teor de nitrogênio na parte aérea (TNPA, \%) e acúmulo de nitrogênio na parte aérea (ANPA, gramas/planta). Para a análise estatística dos dados utilizou-se o teste de médias para as variáveis nos estádios. A estirpe CIAT 899 superou estatisticamente a UFLA 02100 para a maioria das variáveis e constatou-se que a adubação nitrogenada afetou negativamente a nodulação. nitrogênio.

PALAVRAS-CHAVE: Inoculação de sementes. Estádios fenológicos. Fixação biológica de

\section{REFERENCES}

ARAÚJO, F. F.; CARMONA, F. G.; TIRITAN, C. S.; CRESTE, J. E. Fixação biológica de $\mathrm{N}_{2}$ no feijoeiro submetido a dosagens de inoculante e tratamento químico na semente comparado à adubação nitrogenada. Acta Scientiarum Agronomy, Maringá - PR, v. 29, n. 04, p. 535-540, 2007. Disponível em: http://dx.doi.org/10.4025/actasciagron.v29i4.416. Acesso em: 20 mar. 2018.

BARBOSA, F. R.; GONZAGA, A. C. O. Informações técnicas para o cultivo do feijoeiro comum na Região Central-Brasileira 2012-2014. Santo Antônio de Goiás: Embrapa Arroz e Feijão, 2012. 247 p.

BERGAMASCHI, C. Ocorrência de bactérias diazotróficas associadas às raízes e colmos de cultivares de sorgo. 2006, 83 f. Dissertação (Mestrado em Microbiologia Agrícola) - Curso de Pós-Graduação em Microbiologia Agrícola, Universidade Federal do Rio Grande do Sul, Porto Alegre, 2006.

BREDEMEIER, C.; MUNDSTOCK, C. M. Regulação da absorção e assimilação do nitrogênio nas plantas. Ciência Rural, Santa Maria - RS, v. 30, n, 02, p. 365-372, 2000. Disponível em: http://dx.doi.org/10.1590/S0103-84782000000200029. Acesso em: 19 mar. 2018.

BRITO, M. M. P.; MURAOKA, T.; SILVA, E. C. Contribuição da fixação biológica de nitrogênio, fertilizante nitrogenado e nitrogênio do solo no desenvolvimento de feijão e caupi. Bragantia, Campinas - SP, v. 70, n. 01, p. 206-215, 2011. Disponível em: http://dx.doi.org/10.1590/S0006-87052011000100027. Acesso em: 20 mar. 2018.

CASSINI, S. T. A.; FRANCO, M. C. Fixação Biológica de Nitrogênio: microbiologia, fatores ambientais e genéticos. In: VIEIRA, C.; PAULA JR., T. J.; BORÉM, A. (Ed.). Feijão. Viçosa: Ed. UFV, 2008. p. 143-170. 
COMISSÃO TÉCNICA SUL-BRASILEIRA DE FEIJÃO. Informações técnicas para o cultivo de feijão na Região Sul brasileira. 2. ed. Florianopolis: Epagri, 2012. 157 p.

CREGAN, P. B., BERKUM, P. Genetics of nitrogen metabolism and physiological/biochemical selection for increased grain crop productivity. Theoretical and Applied Genetics, Stuttgart - Germany, v. 67, p. 97-111, 1984. Disponível em: http://doi/10.1007/BF00317013. Acesso em: 20 mar. 2018.

EMBRAPA. Empresa Brasileira de Pesquisa Agropecuária. Sistema brasileiro de classificação dos solos. 2. ed. Brasília: Embrapa-CNPSo, 2006. 306 p.

FERNÁNDEZ, F., GEPTS, P., LÓPES, M. Etapas de desarrollo en la planta de frijol común (Phaseolus vulgaris L). Cali: CIAT - Centro Internacional de Agricultura Tropical, 1986. 34 p.

FERREIRA, D. F. SISVAR - Sistema de análise de variância. Versão 5.3. Lavras: UFLA, 2010.

FERREIRA, P. A. A.; SILVA, M. A. P. S.; CASSETARI, A.; RUFINI, M.; MOREIRA, F. M. S. de; ANDRADE, M. J. B. de. Inoculação com cepas de rizóbio na cultura do feijoeiro. Revista Ciência Rural, Santa Maria - RS, v. 39, n. 07, p. 2210-2212, 2009. Disponível em: http://dx.doi.org/10.1590/S010384782009000700041. Acesso em: 20 mar. 2018.

FIGUEIREDO, M. A. Inoculação com Rhizobium spp. e adubações nitrogenada e molibdica no feijoeirocomum. 2012, 99 f. Dissertação (Mestrado em Fitotecnia) - Curso de Pós-Graduação em Agronomia/Fitotecnia, Universidade Federal de Lavras, Lavras, 2012

FONSECA, G. G.; OLIVEIRA, D. P.; SOARES, B. L.; FERREIRA, P. A. A.; TEIXEIRA, C. M.; MARTINS, F. A. D.; MOREIRA, F. M. S.; ANDRADE, M. J. B. Resposta de cultivares de feijoeiro-comum à inoculação das sementes com duas estirpes de rizóbio. Bioscience Journal, v. 29, p. 1778-1787, 2013.

HUNGRIA, M.; CAMPO, R.; CHUEIRE, L.; GRANGE, L.; MEGÍAS, M. Symbiotic effectiveness of fastgrowing rhizobial strains isolated from soybean nodules in Brasil. Biology and Fertility of Soils, Florença Itália, v. 33, n. 05, p. 387-394, 2001. Disponível em: http://doi/10.1007/s003740100338. Acesso em: 20 mar. 2018.

IMSANDE, J.; SCHMIDT, J. M. Effect of N source during soybean pod filling on nitrogen and sulfur assimilation and remobilization. Plant and Soil, Crawley - Austrália, v. 202, p. 41- 47, 1998. Disponível em: http://www.jstor.org/stable/42948341. Acesso em: 20 mar. 2018.

LONG, S. P.; ZHU, X. Z.; NAIDU, S. L.; ORT, D. Can improvement in photosynthesis increase crop yields? Plant, Cell and Environment, United Kingdom, v. 29, p. 315-330, 2006. Available in: http://doi/10.1111/j.13653040.2005.01493.x. Acess: 20 mar. 2018.

MOREIRA, F. M. S; SIQUEIRA, J. O. Microbiologia e bioquímica do solo. Lavras: Editora UFLA, 2002.

PELEGRIN, R.; MERCANTE, F. M.; OTSUB, I. M. N.; OTSUB, A. A. Resposta da cultura do feijoeiro à adubação nitrogenada e à inoculação com rizóbio. Revista Brasileira de Ciência do Solo, Viçosa - MG, v. 33, p. 219-226, 2009. Disponível em: http://dx.doi.org/10.1590/S0100-06832009000100023. Acesso em: 20 mar. 2018.

RECK, S. A. C. Desempenho de genótipos de feijão comum inoculados com estirpes de rizóbio associado à adubação nitrogenada. 2014. 103 f. Tese (Doutorado em Genética e Melhoramento) - Curso de Pós-Graduação em Genética e Melhoramento, Universidade Estadual de Maringá, Maringá, 2014

RIBEIRO, A. C.; GUIMARÃES, P. T. G.; ALVAREZ, V. H. V. Comissão de Fertilidade do Solo do Estado de Minas Gerais. Recomendações para o uso de corretivos e fertilizantes em Minas Gerais - 5ª Viçosa, MG, 1999. $359 \mathrm{p}$. 
SARRUGE, J. R.; HAAG, H. P. Análises químicas em plantas. Piracicaba: ESALQ/USP, 1979. 27 p.

TOLEDO, B. F. B.; MARCONDES, S. J.; LEMOS, E. G. M. Caracterização de rizóbios indicados para produção de inoculantes por meio de sequenciamento parcial do 16S rRNA. Pesquisa Agropecuária Brasileira, Brasília - DF, v. 44, n. 04, p. 384-391, 2009. Disponível em: http://dx.doi.org/10.1590/S0100204X2009000400008. Acesso em: 20 mar. 2018.

VALADÃO, F. C. A.; JAKELAITIS, A.; CONUS, L. A.; BORCHART, L.; OLIVEIRA, A. A.; VALADÃO JUNIOR, D. D. Inoculação das sementes e adubação nitrogenada e molíbdica do feijoeiro-comum, em Rolim de Moura, RO. Acta Amazônica, Manaus - AM, v. 03, p. 741-748, 2009. Disponível em: http://dx.doi.org/10.1590/S0044-59672009000400002. Acesso em: 20 mar. 2018.

VIEIRA, C. Adubação mineral e calagem. In: VIEIRA, C.; PAULA JR., T. J.; BORÉM, A. (Ed.). Feijão. Viçosa: Ed. UFV, 2008. p. 115-142. 